Jurnal Ilmiah Kesehatan Sandi Husada
https://akper-sandikarsa.e-journal.id/JIKSH
Volume 10| Nomor 2| Desember|2021
e-ISSN: 2654-4563 dan p-ISSN: 2354-6093
DOI 10.35816/jiskh.v10i2.677

\title{
Literature Review \\ Efektivitas Ekstrak Lada Hitam (Piper nigrum L) Terhadap Jumlah dan Motilitas Spermatozoa
}

Puji Fauziyyah Iskandar ${ }^{1}$

${ }^{1}$ Fakultas Kedokteran, Universitas Lampung

\section{Article Info Abstract}

Article History:

2021-09-01

Accepted

2021-11-10

Published

2021-12-31

Key words:

Lada hitam;

Jumlah sperma;

Motilitas sperma.
Pendahuluan: Infertilitas merupakan permasalahan utama pada pasangan suami istri dan $40 \%$ disebabkan oleh faktor laki-laki. Hal ini disebabkan oleh peningkatan reactive oxygen species (ROS) yang dapat mempengaruhi kuantitas maupun kualitas spermatozoa sehingga terdapat perubahan jumlah maupun motilitas dari spermatozoa yang diproduksi. Tujuan: mengetahui efektivitas pemberian ekstrak lada hitam (Piper nigrum L) terhadap jumlah dan motilitas spermatozoa. Metode: menggunakan studi literatur dari berbagai sumber jurnal nasional maupun internasional dengan cara meringkas pembahasan, dan membadingkan hasil yang disajikan pada berbagai sumber tersebut. Hasil: lada hitam memiliki kandungan utama piperin yang berperan sebagai antioksidan. Piperin juga dapat meningkatkan hormon gonadotropin terutama luteinizing hormone (LH) yang akan merangsang pembentukan dari spermatozoa atau proses spermatogenesis sehingga berpengaruh terhadap jumlah dan motilitas spermatozoa. Kesimpulan: Pemberian ekstrak lada hitam memiliki pengaruh terhadap jumlah dan motilitas spermatozoa

Introduction: Infertility is a major problem in married couples and $40 \%$ is caused by male factors. This is caused by an increase in reactive oxygen species (ROS) which can affect the quantity and quality of spermatozoa so that there is a change in the number and motility of the spermatozoa produced. Objective: to determine the effectiveness of black pepper extract (Piper nigrum L) on the number and motility of spermatozoa. Method: using literature studies from various national and international journal sources by summarizing the discussion, and comparing the results presented in these various sources. Result: black pepper has the main content of piperine which acts as an antioxidant. Piperine can also increase gonadotropin hormones, especially luteinizing hormone (LH) which will stimulate the formation of spermatozoa or the process of spermatogenesis so that it affects the number and motility of spermatozoa. Conclusion: Giving black pepper extract has an effect on the number and motility of spermatozoa.

\begin{tabular}{ll}
\hline Corresponding author & : Puji Fauziyyah Iskandar \\
Email & : pujifauziyyahi@gmail.com
\end{tabular}


Jurnal Ilmiah Kesehatan Sandi Husada

Volume 10 Nomor 2 Desember 2021

\section{Pendahuluan}

Infertilitas merupakan suatu kondisi ketidakmampuan pasangan untuk mendapatkan kehamilan sekurangnya selama 12 bulan dengan aktif secara seksual dan tanpa kontrasepsi. Menurut Badan Pusat Statistik tahun 2012 di Indonesia angka kejadian infertilitas mengalami peningkatan setiap tahunnya. Menurut data Riskesdas tahun 2013, prevalensi pasangan infertilitas di Indonesia adalah $15-25 \%$ dari seluruh pasangan yang ada. Infertilitas menjadi masalah utama bagi pasangan suami istri dan $40 \%$ disebabkan oleh faktor laki laki (Wiknjosastro, 2011). Faktor lain yang dapat menyebabkan infertilitas diantaranya konsumsi alkohol, merokok, stres, infeksi, radiasi, suhu pada skrotum, obat-obatan dan Reactive Oxygen Species (ROS) (Khaki, 2015). ROS merupakan salah satu radikal bebas yang paling reaktif dan dapat menyebabkan terjadinya peroksidasi lipid pada testis (Kim et al., 2014). Jumlah ROS yang tinggi ini dapat menyebabkan stres oksidatif dan kerusakan pada jaringan testis maupun membran sel sperma sehingga dapat mempengaruhi kesuburan pada pria (Ikhtiar, 2019). Stres oksidatif merupakan kondisi gangguan keseimbangaan antara produksi dari ROS dan antioksidan protektif di dalam tubuh (Sudirman, 2020). Maka dari itu, untuk mencegah terjadinya stres oksidatif dan kerusakan pada organ reproduksi pria diperlukan antioksidan untuk menetralkan ROS di dalam tubuh.

Indonesia merupakan negara dengan hutan tropis terkaya kedua di Dunia, dan menyimpan banyak potensi tanaman sebagai bahan pangan ataupun pengobatan (Robi et al., 2019). Menurut Peraturan Pemerintah Republik Indonesia Nomor 103 Tahun 2014 menyebutkan pada pasal 1 ayat 4 bahwa Obat tradisional merupakan bahan atau ramuan bahan yang berupa bahan tumbuhan, bahan hewan, bahan mineral, sediaan sarian, atau campuran dari bahan tersebut yang secara turun temurun telah digunakan untuk pengobatan, dan dapat diterapkan sesuai dengan norma yang berlaku di masyarakat. Lada hitam (Piper nigrum L) merupakan salah satu tanaman yang digunakan sebagai obat tradisional dan rempah-rempah bagi masyarakat Indonesia. Pada tahun 2016 Indonesia menjadi negara eksportir lada terbesar urutan kelima didunia. Volume ekspor lada pada tahun tersebut ekspor lada mencapai 55,15 ribu ton atau setara dengan 5\% kebutuhan lada di dunia (Nurhayati et al., 2018). Lada hitam memiliki kandungan zat pedas yaitu alkaloid piperin yang berperan sebagai antioksidan (Kardinan, 2018). Selain itu lada hitam juga memiliki beberapa kandungan seperti protein, serat, pati, dan juga sebagai sumber kalsium, mangan, zat besi, vitamin K dan vitamin C bagi tubuh (Salsabila, 2021). Penelitian terdahulu menyebutkan bahwa piperin dapat berpengaruh terhadap reproduksi pria dengan meningkatkan kadar hormon gonadotropin sehingga secara tidak langsung dapat meningkatkan produksi dari hormon testosteron, tetapi pada pemberian piperin dengan dosis tinggi dapat menyebabkan penurunan aktivitas dari enzim antioksidan sehingga terjadi peningkatan ROS yang dapat merusak produksi dari spermatozoa (D’Cruz dan Mathur, 2005). Tujuan mengetahui efektivitas pemberian ekstrak lada hitam terhadap jumlah dan motilitas spermatozoa.

\section{Metode}

Metode yang digunakan oleh penulis adalah studi literatur sistematis dengan langkah analisis meringkas topik dari berbagai sumber pustaka seperti buku dan beberapa jurnal nasional maupun internasional. Penyusunan protokol review digunakan dengan metode PRISMA (Preferred Reporting Items For Systematic Reviews and Meta Analyses). Penelusuran sumber data dilakukan melalui situs Pubmed, google schollar dan situs terpercaya lainnya dengan menggunakan kata kunci pencarian materi "infertilitas pria" "lada hitam" "jumlah spermatozoa" dan "motilitas spermatozoa". Kriteria Inklusi pada jurnal ini yaitu artikel dan jurnal ilmiah yang membahas tentang ekstrak lada hitam yang memberikan pengaruh terhadap reproduksi pria. Melalui pencarian didapatkan 53.169 artikel yang sesuai dengan kata kunci dan hanya sekitar 25 artikel yang dianggap relevan dan memenuhi kriteria inklusi yang sudah ditetapkan. Studi literatur ini dilakukan dengan cara membaca, memahami, dan mereview literatur dari berbagai macam sumber yang ada. Metode ini digunakan dengan tujuan menyajikan, menambah pengetahuan, dan pemahaman mengenai topik yang dibahas dengan meringkas materi yang telah diterbitkan, serta 
memberikan informasi fakta atau analisis terbaru dari tinjauan literatur yang relevan kemudian membandingkan hasil tersebut dalam artikel.

\section{Hasil Dan Pembahasan}

Berbagai studi penelitian menunjukkan beberapa efek pemberian lada hitam maupun piperin terhadap reproduksi pria yang dirangkum pada tabel berikut

Tabel 1

Penelitian mengenai efek pemberian lada hitam dan piperin

\begin{tabular}{|c|c|c|c|}
\hline $\begin{array}{l}\text { Sampel } \\
\text { penelitian }\end{array}$ & Metode & Hasil & Referensi \\
\hline \multirow[t]{3}{*}{ Mencit } & $\begin{array}{l}\text { ekstrak lada hitam } \\
\text { diberikan sebanyak }\end{array}$ & $\begin{array}{l}\text { Libido mencit (latensi } \\
\text { percumbuan, latensi }\end{array}$ & $\begin{array}{l}\text { (Ekaputri, Kanedi, } \\
\text { Sutyarso, \& Busman, }\end{array}$ \\
\hline & $\begin{array}{l}0,3 \text { g kepada } 4 \\
\text { kelompok mencit } \\
\text { yang } \text { dibedakan } \\
\text { berdasarkan umur }\end{array}$ & $\begin{array}{l}\text { penunggangan, dan } \\
\text { frekuensi } \\
\text { penunggangan) }\end{array}$ & 2014) \\
\hline & $\begin{array}{l}\text { Lada hitam diberikan } \\
\text { dengan dosis } \\
25 \mathrm{mg} / \mathrm{kgBB} \text { dan } \\
100 \mathrm{mg} / \mathrm{kg} \text { BB selama } \\
20 \text { dan } 90 \text { hari }\end{array}$ & Histopatologi testis & $\begin{array}{l}\text { (Mishra, \& Singh, } \\
\text { 2009) }\end{array}$ \\
\hline Tikus & $\begin{array}{l}\text { Ekstrak lada hitam } \\
25 \mathrm{mg} \text { diberikan } \\
\text { kepada tikus dengan } \\
\text { berat } 25-30 \mathrm{~g} \text { selama } \\
90 \text { hari }\end{array}$ & $\begin{array}{l}\text { Jumlah spermatozoa, } \\
\text { motilitas spermatozoa, } \\
\text { testosteron level }\end{array}$ & $\begin{array}{l}\text { (Sutyarso, } \\
\text { Muhartono, } \\
\text { Kanedi, 2016) }\end{array}$ \\
\hline Kambing & $\begin{array}{lr}\text { Piperin } & \text { diberikan } \\
\text { dengan } & \text { dosis } \\
\text { sebanyak } & 40 \mu \mathrm{mol} / \mathrm{L},\end{array}$ & $\begin{array}{lr}\text { Viabilitas } & \text { spermatozoa } \\
\text { dan } & \text { motilitas } \\
\text { spermatozoa } & \end{array}$ & $\begin{array}{l}\text { (Janarthanan, Chinta, } \\
\text { Jesthadi, et al., 2014) }\end{array}$ \\
\hline & $\begin{array}{l}60 \quad \mu \mathrm{mol} / \mathrm{L}, \\
\mu \mathrm{mol} / \mathrm{L}, \quad \text { dan } \\
\mu \mathrm{mol} / \mathrm{L}\end{array}$ & & \\
\hline
\end{tabular}

\section{Pembahasan}

Infertilitas merupakan ketidakmampuan pasangan usia subur untuk memiliki keturunan selama satu tahun. Infertilitas dibagi menjadi dua yaitu, infertilitas primer dan sekunder. Infertilitas primer merupakan ketidakmampuan pasangan memiliki keturunan selama satu tahun dengan berhubungan seksual secara rutin tanpa kontrasepsi dan belum pernah hamil sebelumnya. Sedangkan, infertilitas sekunder merupakan ketidakmampuan pasangan usia subur memiliki keturunan selama satu tahun dengan berhubungan seksual secara rutin tanpa kontrasepsi dan sudah pernah mendapatkan kehamilan sebelumnya (Oktarina et al., 2014). Infertilitas dapat disebabkan oleh faktor perempuan maupun laki-laki. Infertilitas yang disebabkan oleh faktor perempuan diantaranya gangguan pada tuba fallopi, uterus, serviks dan vagina. Sedangkan infertilitas yang disebabkan oleh faktor pria diantaranya varikokel, kelainan morfologi, jumlah, maupun motilitas dari spermatozoa (Dhyani et al., 2020). Faktor lain yang dapat menyebabkan infertilitas adalah konsumsi alkohol, merokok, stres, obat-obatan dan ROS (Khaki, 2015).

Pemeriksaan pada pasangan infertilitas dilakukan pada wanita maupun pria. Pemeriksaan pada pria meliputi pemeriksaan analisis sperma untuk melihat kualitas maupun kuantitas dari spermatozoa. Secara umum analisis sperma melihat dua karakteristik yaitu makroskopik dan mikroskopik spermatozoa. Analisis spermatozoa secara makroskopik meliputi bau, warna, 
Jurnal Ilmiah Kesehatan Sandi Husada

Volume 10 Nomor 2 Desember 2021

volume, viskositas, dan $\mathrm{pH}$. Sedangkan analisis spermatozoa secara mikroskopik meliputi beberapa parameter seperti konsentrasi, jumlah, morfologi, dan motilitas spermatozoa (HIFERI, 2013). Sel spermatozoa pada mamalia memiliki kompisisi lipid yang spesifik pada membran sperma untuk kemampuan fungsional dari sel tersebut. Namun, disisi lain komposisi lipid tersebut mudah untuk teroksidasi oleh ROS sehingga dapat menyebabkan terjadinya stres oksidatif. Stres oksidatif yang terjadi pada sel spermatozoa ini dapat menimbulkan beberapa kerusakan seperti kerusakan pada DNA sperma dan dapat menurunkan produksi atau jumlah dari spermatozoa, maupun motilitas spermatozoa (Rahmadiani, 2021).

Menurut WHO (2010) jumlah spermatozoa normal adalah sebanyak 40 juta atau lebih setiap ejakulasinya. Penurunan jumlah spermatozoa dapat disebabkan oleh beberapa faktor salah satunya yaitu nutrisi pada sperma (Guyton et al., 2014). Sedangkan faktor yang dapat meningkatkan jumlah dari spermatozoa adalah peningkatan proses dari pembentukan sperma itu sendiri yang disebut spermatogenesis. Perhitungan jumlah spermatozoa dilakukan berdasarkan lapang pandang yang diamati pada improved neubauer dan dikalikan dengan $10^{6}$ (Gandasoebrata, 2013). Motilitas spermatozoa merupakan kemampuan gerak dari spermatozoa untuk membuahi sel telur (Wahyuningsih et al., 2013). Motilitas spermatozoa yang baik adalah sperma yang bergerak lurus kedepan dengan gerakan lincah dan cepat. Nilai normal motilitas spermatozoa yang bergerak lurus kedepan adalah lebih dari 50\% (Strasinger dan Lorenzo, 2014). Faktor yang dapat mempengaruhi penurunan motilitas dari spermatozoa yaitu nutrisi, abnormalitas spermatozoa, dan usia spermatozoa. Semakin banyak sperma yang abnormal makan semakin rendah kemampuan daya gerak dari sperma tersebut.

Lada hitam merupakan buah dari tanaman piper nigrum yang dikeringkan dan digunakan sebagai bahan pangan rempah (Mohammed et al., 2016). Lada hitam memiliki beberapa kandungan kimia diantaranya saponin, flavonoid, minyak atsiri, kavisin, resin, zat putih telur, amilum, piperin, piperiline, piperoleine, poperanine, piperonal, dihidrokarveol, kanyo-fillene oksida, kariptone, tran piocarrol, dan minyak lada (Susila dan Nasihah, 2019). Piperin diketahui memiliki 4 struktur isomer diantaranya piperin (trans-trans isomer), isopiperin (cis-trans isomer), chavicin (cis-cis isomer), dan isochavicin (trans-cis isomer) (Hammouti et al., 2019). Penelitian terbaru menyebutkan bahwa piperin memiliki peran sebagai antioksidan, imun modulator, antikanker, hepatoprotective, antiinflamasi, antiulserasi, dan antimikroba. Piperin juga dilaporkan dapat menghambat terjadinya stres oksidatif, dan digunakan sebagai proteksi terhadap radikal bebas, ROS, dan penghambatan peroksidasi lemak (Salsabila, 2021).

Berdasarkan penelitian yang dilakukan oleh Ekaputri, Sutyarso, Kanedi, dan Busman pada tahun (2014) didapatkan hasil, pemberian ekstrak etanol lada hitam 0,3 g pada mencit jantan dapat meningkatkan libido dengan cara mempersingkat latensi percumbuan pada mencit tua dan mempersingkat frekuensi penunggangan pada mencit usia muda. Hal ini berkaitan dengan meningkatkanya level testosteron yang juga dapat mempengaruhi produksi dari spermatozoa. Dengan hal tersebut dapat diduga bahwa pemberian ekstrak lada hitam dapat meningkatkan jumlah dan motilitas spermatozoa. Penelitian lainnya yang dilakukan oleh Sutyarso, Muhartono, dan Kanedi (2016) menyebutkan pemberian ekstrak lada hitam 25 mg selama 90 hari pada tikus albino jantan dengan berat $25-30 \mathrm{~g}$ dapat meningkatkan jumlah dan motilitas spermatozoa. Penelitian menggunakan mencit sebelumnya juga dilakukan oleh Raghav Kumar Mishra dan Shio Kumar Singh (2009) dengan hasil, pemeberian lada hitam dengan dosis $25 \mathrm{mg} / \mathrm{kgBB}$ dan 100 $\mathrm{mg} / \mathrm{kgBB}$ memberikan perubahan hasil perbaikan pada histopatologi testis menci dibandingkan dengan pemberian selama 20 hari. Pada Penelitian Rajesh Janarthanan, Gopichand Chinta, Dineshbabu Jesthadi, Latha Periyasamy, Bavatharini Shanmuganathan (2014) didapatkan hasil, pemberian piperin dengan dosis sebanyak $40 \mu \mathrm{mol} / \mathrm{L}, 60 \mu \mathrm{mol} / \mathrm{L}, 80 \mu \mathrm{mol} / \mathrm{L}$, dan $100 \mu \mathrm{mol} / \mathrm{L}$ pada kambing secara signifikan dapat menurunkan motilitas spermatozoa. 


\section{Simpulan Dan Saran}

Lada hitam merupakan tanaman yang memiliki peran sebagai antioksidan sehingga dapat menetralkan ROS. Peningkatan ROS dalam tubuh dapat menurunkan jumlah maupun motilitas dari spermatozoa. Piperin merupakan kandungan utama lada hitam yang diduga dapat meningkatkan hormon testosteron secara tidak langsung.

\section{Daftar Rujukan}

D'cruz, S. C., Mathur, P. P. (2005). Effect of Piperine on the Epididimys of Adult Male Rats Asian. Journal of Andrology, 7(4), 363-368.

Dhyani, I. A. D., Kurniawan, Y., Negara. M. O. (2020). Hubungan Antara Faktor-faktor Penyebab Infertilitas Terhadap Tingkat Keberhasilan IVF-ICSI RSIA Puri Bunda Denpasar Pada Tahun 2017. Jurnal Medika Udayana, 9(5), 23-29.

Ekaputri, T. W., Kanedi, M., Sutyarso, Busman, H. (2014). Efek Ekstrak Lada Hitam (Piper nigrum L.) Terhadap Libido Mencit (Mus musculus L.) Jantan Yang Berbeda Umur. Jurnal Ilmiah: Biologi Eksperimen dan Keanekaragaman Hayati, 2(1), 1-5.

Gandasoebrata, R. (2013). Penuntun Laboratorium Klinis. Jakarta: Dian Rakyat.

Guyton, A. C., Hall, J. E. (2014). Buku Ajar Fisiologi Kedokteran Edisi 12. Jakarta: EGC.

Hammouti, B., Dahmani, M., Yahyi, A., Ettouhami, A., Messali, M., Asehraou, A., Bouyanzer, A., Warad, I., Touzani, R. (2019). Black pepper, the "King of Species": Chemical composition to applications. Arabian Journal of Chemical and Enviromental Research, $6(1), 12-56$.

HIFERI. (2013). Konsensus Penangan Infertilitas. Jakarta: Himpunan Endokrinologi Reproduksi dan Fertilitas Indonesia, Perhimpunan Fertilitas In Vitro Indonesia, Ikahatan Ahli Urologi Indonesia, Perkumpulan Obstetri dan Ginekologi Indonesia.

Ikhtiar, F. (2019). Pengaruh Tomat (Solanum lycopersicum) terhadap Diameter Tubulus Seminiferus Tikus Putih (Rattus norvegicus) Galur Sprague dawley yang Diinduksi Gentamisin. Jurnal Mandala Pharmacon Indonesia, 5(1), 38-42.

Kardinan, A., Laba, I. W., Rismayani. (2018). Peningkatan Dayasaing Lada (Piper nigrum L.) Melalui Budidaya Organik. Jurnal Perspektif Balai Penelitian Tana, an Rempah dan Obat, 17(1), 26-39.

Khaki, A. (2015). Assessment on the adverse effects of Aminoglycosides and Flouroquinolone on sperm parameters and male reproductive tissue: A systematic review. Iran J Reprod Med, 13(3), 125-134.

Kim, S. H., Lee, I. C., Baik, H. S., Shin, I. S., Moon, C., Yun, W. K., Nam, K. H., Kim, H. C. Kim, J. C. (2014). Melatonin prevents gentamicin-induced testicular toxicity and oxidative stress in rats. Andrologia, 46(9), 1032-1040.

Mishra, R. K., Singh, S. K. (2009). Antispermatogenic and antifertility effects of fruits of Piper nigrum L. in mice. Indian J Exp Biol, 47(9), 706-714.

Mohammed, G. J., Omran, A. M., Hussein, H. M. (2016). Antibacterial and Phytochemical Analysis of Piper nigrum using Gas Chromatography-Mass Spectrum and FourierTransform Infrared Spectroscopy. Internasional Journal of Pharmacognosy and Phytochemical Research, 8(6), 977-996.

Nurhayati, E., Hartoyo, S., Mulatsih, S. (2018). Pengembangan Pasar Ekspor Lada Indonesia. Buletin Ilmiah Litbang Perdagangan, 12(2), 267-288

Oktarina, A., Abadi, A., Bachsin, R. (2014). Faktor-faktor yang Mempengaruhi Infertilitas pada Wanita di Klinik Fertilitas Endokrinologi Reproduksi. Majalah Kedokteran Sriwijaya, 46(4), 295-300.

Rahmadiani, D. (2021). Ekstrak Pollen Kurma (Phoenix dactylifera L) Sebagai Terapi Infertilitas Pada Pria. Jurnal Ilmiah Kesehatan Sandi Husada, 10(1), 31-40.

Robi, Y., Kartikawati, S. M., Muflihati. (2019). Etnobotani Rempah Tradisional di Desa Empoto Kabupaten Sanggau Kalimantan Barat. Jurnal Hutan Lestari, 7(1), 130-142. 
Salsabila, H. A. 2021. Efektivitas Ekstrak Lada Hitam (Piper nigrum L.) dan Zink (Zn) Terhadap Viabilitas dan Morfologi Sperma. Jurnal Medika Hutama, 3(1), 1507-1511.

Strasinger, S. K., Lorenzo, S. M. (2014). Urinalysis and Body Fluied 6th Edition. United States: FA Davis Company.

Sudirman, A. W. (2020). Pengaruh Radiasi Gelombang Elektromagnetik Telepon Genggam Terhadap Perkembangan Sperma. Jurnal Ilmiah Kesehatan Sandi Husada, 9(2), 708-712.

Susila, I., Nasihah, M. (2019). Pengaruh Cream Biji Lada Hitam (Piper nigrum L.) Terhadap Penyakit Vitiligo. Jurnal Nasional Ilmu Kesehatan, 1(3), 28-44.

Sutyarso, M., Kanedi, M., Muhartono. (2016). The effect of fruit extracts of black pepper on the fertility potential of male albino rats. American Journal of Medical and Biological Research, 4(1), 1-4.

Wahyuningsih, A., Saleh, D. M., Sugiyanto. (2013). Pengaruh Umur Pejantan dan Frekuensi Penampungan Terhadap Volume dan Motilitas Semen Segar Sapi Simental di Balai Inseminiasi Buatan Lembang. Jurnal Ilmiah Peternakan, 1(3), 947-953.

Wiknjosastro, H. (2011). Ilmu Kandungan. Jakarta: Yayasan Bina Pustaka Sarwono Prawirohardjo

World Health Organization (2010). WHO Laboratory Manual for the Examination and Processing of Human Semen. England: Cambridge University Press. 